\title{
Gambaran Strategi Koping Keluarga dalam Merawat Anggota Keluarga yang Menderita Gangguan Jiwa Berat
}

\author{
Yelsi Wanti, Efri Widianti, Nita Fitria \\ Fakultas Keperawatan Universitas Padjadjaran \\ Email:efree358@yahoo.com
}

\begin{abstract}
Abstrak
Keluarga yang merawat anggota keluarga dengan gangguan jiwa sering mengalami stres karena perilaku anggota keluarga yang mengalami gangguan jiwa dan stigma yang melekat pada keluarga. Keluarga akan melakukan strategi koping untuk mengatasi stres yang dialami. Tujuan Penelitian ini adalah untuk mengidentifikasi strategi koping keluarga dalam merawat anggota keluarga yang menderita gangguan jiwa berat di rumah di Desa Sukamaju dan Desa Kersamanah Kecamatan Kersamanah Kabupaten Garut. Jenis penelitian ini adalah deskriptif kuantitatif dengan jumlah responden sebanyak 43 orang anggota keluarga yang merawat pasien gangguan jiwa berat, diambil dengan total sampling. Data penelitian diambil menggunakan kuesioner dari instrumen baku Ways Of Coping (WOC) dan analisis data yang digunakan dalam bentuk persentase. Hasil penelitian menunjukkan sebagian dari responden yaitu 20 orang $(47 \%)$ lebih cenderung menggunakan emotional focused coping, sebagian kecil responden yaitu 13 orang $(30 \%)$ cenderung menggunakan problem focused coping dan sebagian kecil responden lainnya yaitu 10 orang $(23 \%)$ dominan menggunakan problem focused coping dan emotional focused coping secara bersamaan. Simpulan dari penelitian ini menunjukkan bahwa keluarga dalam merawat pasien gangguan jiwa berat di rumah melakukan usaha untuk menghadapi stres dengan cara mengatur respon emosionalnya untuk menyesuaikan diri dari dampak yang ditimbulkan oleh pasien. Hasil penelitian ini diharapkan dapat memberikan masukan bagi perawat di puskesmas setempat untuk memberikan konsultasi dan konseling bagi keluarga dalam merawat pasien gangguan jiwa berat di rumah.
\end{abstract}

Kata kunci: Gangguan jiwa berat, keluarga, strategi koping.

\section{Describe Of Family Coping Strategies In Caring Family Members Suffering From Severe Mental Disorders}

\begin{abstract}
Families who care for family members with mental illness often stresor due to the behavior of family members with mental illness and the stigma attached to the family. The family will do the coping strategies to overcome the stres experienced. The study purpose is to identify family coping strategies in caring for family members who suffer from severe mental disorders at home in Sukamaju and Kersamanah Villages in District of Garut. This design of study is quantitative descriptive with the number of respondents about 43 family members who care for patients with severe mental disorders, using total sampling. The data were taken using a questionnaire of raw instrument Ways Of Coping (WOC) and data analysis used form of a percentage. The results showed the majority of respondents, 20 people $(47 \%)$ were more likely to use emotional focused coping, a small portion 13 respondents $(30 \%)$ tend to use problem focused coping and a small portion 10 respondents $(23 \%)$ predominantly use problem focused coping and emotional focused coping simultaneously. The conclusions of this study indicate that the family in caring for patients with severe mental disorders at home to make efforts to deal with stres by regulating the emotional response to adjust from the impact caused by the patient. The results of this study are expected to provide input for a nurse at a Health care to provide consultation and counseling for families in caring for patients with disorders severe mental at home.
\end{abstract}

Keywords: Coping strategies, family, severe mental disorders. 
Yelsi Wanti: Gambaran Strategi Koping Keluarga dalam Merawat Anggota Keluarga

\section{Pendahuluan}

Berdasarkan data Riset Kesehatan Dasar tahun 2013, di Jawa Barat prevalensi gangguan jiwa berat sebesar 1,6 permil atau dapat diartikan 1-2 orang dari 1.000 warga Jawa Barat mengalami gangguan jiwa berat. Selain itu, prevalensi gangguan jiwa berat di daerah pedesaan ternyata lebih tinggi dibanding daerah perkotaan. American Psychiatric Association dalam Videbeck (2008) mendefinisikan gangguan jiwa sebagai suatu sindrom atau pola psikologis atau perilaku yang terjadi pada seseorang dan dikaitkan dengan adanya distres (gejala yang menyakitkan) atau disabilitas (kerusakan pada satu atau lebih area yang penting) yang dapat meningkatkan risiko terhadap kematian, nyeri, ketidakmampuan atau kehilangan.

Pada dasarnya gangguan jiwa dibagi menjadi 2 yaitu: Gangguan jiwa berat/ psikosa dan gangguan jiwa ringan/neurosa. Gangguan jiwa berat ditandai dengan 2 gejala utama yaitu kurangnya pemahaman diri (insight) dan ketidakmampuan menilai realitas (Reality Testing Ability/ RTA) (Mohr, 2006). Videbeck (2008) menyatakan bahwa psikotik adalah suatu gangguan jiwa dengan kehilangan rasa kenyataan (sense of reality). Kelainan seperti ini dapat diketahui berdasarkan gangguan-gangguan pada perasaan, pikiran, kemauan, motorik, dan lainnya, sedemikian berat sehingga perilaku penderita tidak sesuai lagi dengan kenyataan.

Adanya anggota keluarga yang mengalami gangguan jiwa berat menjadi beban bagi keluarga. Beban tersebut sering kali terjadi karena keluarga tidak memiliki pemahaman akan kebutuhan pasien, dan tingkah laku pasien sulit dimengerti sehingga mempersulit terjalinnya hubungan antara keluarga dan pasien. Keluarga sulit membina dialog dengan pasien sehingga menimbulkaan stres dalam keluarga (Setiadi, 2006).

Keluarga merupakan unit yang paling dekat dengan pasien dan merupakan perawat utama bagi pasien. Keluarga berperan dalam menentukan cara atau asuhan yang diperlukan di rumah. Friedman (2010) menjelaskan bahwa keluarga dalam memenuhi kebutuhan kehidupannya memiliki fungsi-fungsi dasar keluarga salah satunya adalah fungsi perawatan kesehatan. Ada 5 tugas yang berlaku dalam fungsi perawatan kesehatan yaitu: mengenal masalah kesehatan, membuat keputusan tindakan kesehatan yang tepat, memberi perawatan pada anggota keluarga yang sakit, mempertahankan atau menciptakan suasana rumah tangga yang sehat, dan menggunakan fasilitas kesehatan masyarakat.

Merawat anggota keluarga yang mengalami gangguan jiwa berat merupakan stresor bagi keluarga. Stres dan beban yang dialami oleh keluarga sebagai primary caregiver dapat berupa beban fisik dan mental (Fausiah, 2005 dalam Nainggolan \& Hidajat, 2013). Stres yang dialami oleh keluarga yang merawat kerabat dengan gangguan jiwa dipengaruhi oleh stigma dan beban yang dialami seperti biaya pengobatan, biaya transportasi dan tergangguanya pola tidur mereka (Magana et al., 2007). Stres adalah keadaan yang menekan dan membahayakan individu serta telah melampaui sumber daya yang dimiliki. Dalam merawat pasien dengan gangguan jiwa, keluarga akan melakukan strategi koping untuk mengatasi stres. Koping merupakan upaya kognitif dan perilaku untuk mengelola tuntutan eksternal/ internal tertentu yang dinilai membebani atau melewati batas sumber daya yang ada dalam diri seorang individu. Strategi koping merupakan perubahan dari suatu kondisi ke lainnya sebagai cara untuk menghadapi situasi tak terduga (Lazarus \& Folkman, 1984). Friedman (2010) menyatakan bahwa strategi koping merupakan perilaku atau proses untuk adaptasi dalam menghadapi tekanan atau ancaman.

Lazarus dan Folkman, (1984 dalam Nasir dan Muhith, 2011) secara umum membedakan koping dalam 2 klasifikasi yaitu: Problem Focused Coping (PFC) atau koping yang berfokus pada masalah dan Emotional Focused Coping (EFC) atau koping yang berfokus pada emosi. PFC dibagi dalam beberapa klasifikasi yaitu: confrontive coping, planful problem solving, dan seeking social support. Adapun pengelompokan dari EFC ini yaitu: distancing, self control, accepting responsibility, positive reappraisal, dan escape/avoidance.

Hasil dari studi pendahuluan di Kecamatan Kersamanah Kabupaten Garut, dilihat dari 
Yelsi Wanti: Gambaran Strategi Koping Keluarga dalam Merawat Anggota Keluarga

data Puskesmas Sukamerang. Total keluarga yang merawat anggota keluarganya yang ganguan jiwa berat di Desa Sukamaju dan Desa Kersamanah kabupaten garut sebanyak 43 keluarga. Dalam merawat, masih ada anggota keluarga yang kurang peduli akan masalah kesehatan jiwa anggota keluarganya walaupun mereka mengetahui pasien mengalami gangguan jiwa. Beberapa keluarga tidak peduli akan aktivitas yang dilakukan pasien, jarang menegur pasien dan hanya terkadang mengingatkan pada kebersihan diri dan minum obat.

Strategi koping yang dilakukan cukup bervariasi ada diantara anggota keluarga yang mencoba berpikir bahwa memang sudah menjadi tugas mereka untuk merawat pasien karena mereka adalah orang terdekat pasien dan yang paling merasakan dampak dari gangguan jiwa yang diderita pasien. Ada yang memilih melakukan pekerjaan lain jika telah lelah merawat dan untuk sementara waktu mengabaikan pasien. Kemudian, ada yang meminta bantuan dan saran pada tetangga, kerabat dan petugas puskesmas untuk mencari solusi penanganan pasien. Tidak lupa mereka selalu berdoa untuk kesembuhan keluarganya. Masih ada keluarga yang menjadi marah pada pasien gangguan jiwa jika mengalami kekambuhan ataupun saat pasien menolak minum obat.

Berdasarkan fenomena tersebut peneliti tertarik untuk mengetahui gambaran strategi koping keluarga dalam merawat anggota keluarga yang menderita gangguan jiwa berat di rumah Desa Sukamaju dan Desa Kersamanah Kecamatan Kersamanah Kabupaten Garut.

\section{Metode Penelitian}

Jenis penelitian yang digunakan adalah penelitian deskriptif kuantitatif. Penelitian deskriptif adalah metode penelitian yang dilakukan dengan tujuan utama membuat gambaran tentang sesuatu keadaan objektif. Penelitian ini untuk mengetahui gambaran strategi koping keluarga dalam merawat anggota keluarga yang menderita gangguan jiwa berat di rumah di Desa Sukamaju dan Desa Kersamanah Kecamatan Kersamanah Kabupaten Garut.
Dalam penelitian ini pengambilan sampel dilakukan dengan cara total sampling yaitu sebanyak 43 orang anggota keluarga. Anggota keluarga yang dimaksud pada penelitian ini adalah anggota keluarga yang merupakan caregiver pasien dan bertanggung jawab merawat anggota keluarganya yang mengalami gangguan jiwa berat di rumah. Instrumen pada penelitian ini adalah kuesioner. Kuesioner terdiri dari 66 pertanyaan tentang strategi koping yang diambil dari instrumen baku Ways of Coping (WOC) berdasarkan teori yang digunakan oleh Lazarus dan Folkman (1988). Skoring dilakukan dengan cara meranking jawaban responden dalam bentuk skala likert, dimana jawaban diberi skor $3=$ sangat sering, $2=$ sering, $1=$ jarang, $0=$ tidak pernah, sehingga diperoleh data dengan skala pengukuran nominal.

Teknik pengumpulan data dengan menggunakan kuesioner tertutup. Peneliti mengunjungi rumah-rumah responden, kemudian meminta kesediaan responden untuk mengisi kuesioner, setelah dilakukan penjelasan tujuan penelitian. Responden menjawab lembar isian kuesioner dengan memilih jawaban sesuai dengan perasaan saat ini, dari salah satu jawaban dengan memberi tanda checklist $(\sqrt{ })$.

Analisa data yang digunakan dalam penelitian ini adalah statistik deskriptif dalam bentuk analisis persentase (\%) berdasarkan hasil kuesioner. Analisis deskriptif/ analisis univariate digunakan untuk menjelaskan atau mendeskripsikan karakteristik setiap variabel yang ada, pada penelitian ini yaitu strategi koping.

\section{Hasil Penelitian}

Hasil penelitian mengenai gambaran strategi koping keluarga dalam merawat anggota keluarganya yang menderita gangguan jiwa berat di Desa Sukamaju dan Kersamanah Kabupaten Garut.

Berdasarkan tabel 1 dapat diketahui bahwa sebagian dari responden yaitu 20 orang $(47 \%)$ lebih cenderung menggunakan emotional focused coping dalam menghadapi beban merawat anggota keluarga yang mengalami gangguan jiwa berat, sedangkan 
Yelsi Wanti: Gambaran Strategi Koping Keluarga dalam Merawat Anggota Keluarga

Tabel 1 Distribusi Frekuensi Strategi Koping Keluarga dalam Merawat Anggota Keluarga yang Mengalami Gangguan Jiwa Berat di Rumah $(n=43)$

\begin{tabular}{lcc}
\hline \multicolumn{1}{c}{ Strategi Koping } & f & \% \\
\hline Problem Focused Coping & 13 & 30 \\
Emotional Focused Coping & 20 & 47 \\
Keduanya (PFCdan EFC) & 10 & 23 \\
\hline
\end{tabular}

Tabel 2 Distribusi Frekuensi Strategi Koping Berdasarkan Subvariabel Problem Focused Coping yang Dilakukan Keluarga dalam Merawat Anggota Keluarga yang Gangguan Jiwa Berat di Rumah ( $n=13)$

\begin{tabular}{llc}
\hline Problem Focused Coping (PFC) & f & \% \\
\hline Confrontive Coping & 1 & 8 \\
Planful Problem Solving & 7 & 54 \\
Seeking Social Support & 4 & 30 \\
Confrontive dan Planful Problem & 1 & 8 \\
Solving & & \\
\hline
\end{tabular}

Tabel 3 Distribusi Frekuensi Strategi Koping Berdasarkan Subvariabel Emotional Focused Coping yang Dilakukan Keluarga dalam Merawat Anggota Keluarga yang Menderita Gangguan Jiwa Berat di Rumah ( $\mathbf{n = 2 0})$

\begin{tabular}{lcc}
\hline \multicolumn{1}{c}{ Emotional Focused Coping $(\boldsymbol{E F C})$} & f & \% \\
\hline Distancing & 3 & 15 \\
Accepting Responsibility & 2 & 10 \\
Self Control & 1 & 5 \\
Positive reappraisal & 11 & 55 \\
Excape/ avoidance & 1 & 5 \\
Self Control \& Positive reappraisal & 1 & 5 \\
Accepting Responsibility \& Positive reappraisal & 1 & 5 \\
\hline
\end{tabular}

Tabel 4 Distribusi Frekuensi Strategi Koping PFC dan EFC yang Dilakukan Keluarga dalam Merawat Anggota Keluarga yang Menderita Gangguan Jiwa Berat $(n=10)$

\begin{tabular}{|c|c|c|}
\hline PFC dan EFC & f & $\%$ \\
\hline Seeking Social Support \& Accepting Responsibility & 3 & 30 \\
\hline Seeking Social Support \& Positive reappraisal & 3 & 30 \\
\hline Planful Problem Solving \& Distancing & 1 & 10 \\
\hline $\begin{array}{l}\text { Planful Problem Solving, Accepting Responsibility \& Positive } \\
\text { reappraisal }\end{array}$ & 1 & 10 \\
\hline $\begin{array}{l}\text { Planful Problem Solving, Seeking Social Support \& Positive } \\
\text { reappraisal }\end{array}$ & 1 & 10 \\
\hline $\begin{array}{l}\text { Planful Problem Solving, Seeking Social Support, Accepting } \\
\text { Responsibility \& Self Control }\end{array}$ & 1 & 10 \\
\hline
\end{tabular}

sebagian kecil responden yaitu 13 orang (30\%) menggunakan problem focused coping dan sebagian kecil responden lainnya yaitu 10 orang (23\%) yang dominan menggunakan problem focused coping dan emotional focused coping secara bersamaan. Data yang didapat dari 13 responden yang cenderung menggunakan problem focused coping, 
Yelsi Wanti: Gambaran Strategi Koping Keluarga dalam Merawat Anggota Keluarga

menunjukkan bahwa setengah dari responden yaitu 7 orang $(54 \%)$ lebih cenderung menggunakan planful problem solving dalam menghadapi beban selama merawat anggota keluarga yang gangguan jiwa dan sebagian kecil responden yaitu 4 orang (30\%) lebih cenderung menggunakan seeking social support (Tabel 2).

Berdasarkan tabel 3, dari 20 responden yang cenderung menggunakan emotion focused coping, menunjukkan bahwa setengah dari responden yaitu 11 orang $(55 \%)$ lebih cenderung menggunakan positive reappraisal dalam menghadapi beban selama merawat anggota keluarga yang menderita gangguan jiwa berat. sangat sedikit responden yaitu 3 orang $(15 \%)$ yang lebih cenderung menggunakan distancing dan 2 orang (10\%) lebih cenderung menggunakan accepting responsibility. Berdasarkan tabel 4, dari 10 responden yang dominan menggunakan strategi koping keduanya yaitu PFC dan EFC, menunjukkan bahwa 3 orang responden $(30 \%)$ lebih cenderung menggunakan seeking social support dan accepting responsibility secara bersamaan dan 3 orang lainnya (30\%) lebih cenderung menggunakan seeking social support dan positive reappraisal secara bersamaan dalam menghadapi beban selama merawat anggota keluarga yang menderita gangguan jiwa berat.

\section{Pembahasan}

Berdasarkan pada tabel 1 menunjukkan bahwa dari 43 responden menunjukkan bahwa sebagian dari responden yaitu 20 orang $(47 \%)$ lebih cenderung menggunakan emotional focused coping. Ini menandakan keluarga dalam merawat klien gangguan jiwa berat di rumah melakukan usaha untuk menghadapi stres dengan cara mengatur respon emosionalnya untuk menyesuaikan diri dari dampak yang ditimbulkan oleh klien. Sebagian kecil responden yaitu 13 orang $(30 \%)$ lebih cenderung menggunakan problem focused coping dan sebagian kecil lainnya yaitu 10 orang (23\%) lebih dominan menggunakan strategi koping problem focused coping dan emotional focused coping secara bersamaan.

Adanya anggota keluarga yang mengalami gangguan jiwa berat, akan mengakibatkan beban bagi keluarga. Beban tersebut sering kali terjadi karena keluarga tidak memiliki pemahaman akan kebutuhan pasien, dan tingkah laku pasien sulit untuk dimengerti. Keluarga sulit membina dialog dengan pasien sehingga menimbulkaan stres dalam keluarga. Sehingga keluarga merasa kelelahan dengan tanggung jawab dalam merawat klien gangguan jiwa berat (Setiadi, 2006).

Menurut Lazarus dan Folkman (1984) individu cenderung menggunakan emotional focused coping dalam menghadapi masalahmasalah yang menurut mereka sulit untuk dikontrol. Stres yang ditimbulkan oleh pasien gangguan jiwa berat ini akan sulit untuk dikontrol oleh keluarga, sehingga anggota keluarga akan lebih cenderung menggunakan emotional focused coping untuk mengatur respon emosionalnya dan menyesuaikan diri dari dampak yang ditimbulkan pasien. Penggunaan emotional focused coping dalam merawat pasien gangguan jiwa berat lebih tinggi daripada problem focused coping sesuai dengan hasil penelitian Rammohan, Rao, dan Subbakrishna (2002) yang menyatakan beban yang dirasakan paling tinggi dalam merawat pasien dengan gangguan jiwa berat adalah beban emosional dan untuk mengatasi beban tersebut keluarga cenderung melakukan emotional focused coping. Kemudian hasil penelitian yang dilakukan Retnowati (2012) yang menyatakan bahwa strategi koping yang banyak digunakan yang berhubungan dengan keluarga dalam merawat pasien skizofrenia adalah emotional focused coping. Emotional focused coping memungkinkan seseorang untuk mengidentifikasi permasalahan yang dihadapi, mengolah permasalahan, dan mengekspresikannya dalam bentuk emosi sehinggaemotionalfocused copingmerupakan strategi koping aktif yang dilakukan oleh seorang dan mengandung tujuan tertentu (Baker \& Berenbaum, 2008). Dalam menghadapi keluarga yang menggunakan emotional focused coping maka pendekatan konseling keperawatan dan psikoterapi yang terkait dengan penyelesaian masalah emosi seperti Rational Emotive Behavoiur Therapy tepat digunakan (McMahon, 1998 \& Sacks, 2004).

Keluarga yang cenderung menggunakan problem focused coping merupakan keluarga 
Yelsi Wanti: Gambaran Strategi Koping Keluarga dalam Merawat Anggota Keluarga

yang menganggap masalah dapat dikontrol sehingga untuk mengatasi stres, mereka berusaha untuk mengubah masalah yang dihadapi (Lazarus \& Folkman, 1984). Dalam hal ini keluarga akan lebih melaksanakan fungsi keperawatan keluarga yaitu mengenal masalah kesehatan, membuat keputusan tindakan kesehatan yang tepat, memberi perawatan pada anggota keluarga yang sakit, mempertahankan atau menciptakan suasana rumah tangga yang sehat, mempertahankan hubungan dengan (menggunakan) fasilitas kesehatan masyarakat (Friedman, 2010).

Tabel 2 menunjukkan bahwa dari 13 responden yang menggunakan problem focused coping menunjukkan bahwa setengah dari responden yaitu 7 orang (54\%) lebih cenderung menggunakan planful problem solving dalam menghadapi masalah. Ini menandakan bahwa keluarga dalam merawat anggota keluarganya yang mengalami gangguan jiwa berat lebih berusaha untuk mengubah keadaan dengan cara hati-hati, bertahap dan direncanakan. Keluarga yang menggunakan strategi koping planful problem solving dalam merawat pasien gangguan jiwa berat, mereka menyusun rencana apa saja yang harus dikerjakan dalam merawat, menyediakan keperluan pasien serta membantu dan mengawasi pasien minum obat secara teratur. Dalam hal ini keluarga akan berusaha untuk dapat mengenal masalah kesehatan, mengambil keputusan tindakan kesehatan yang tepat, memberi perawatan kepada pasien dan memodifikasi lingkungan yang baik untuk pasien (Friedman, 2010)

Selain itu, sebagian kecil responden yaitu 4 orang $(30 \%)$ lebih cenderung menggunakan seeking social support dalam mengatasi masalah. Ini menandakan keluarga dalam merawat anggota keluarganya yang mengalami gangguan jiwa berat lebih berusaha untuk mencari dukungan sosial, meminta informasi dari orang lain seperti kerabat ataupun orang yang lebih profesional. Keluarga yang menggunakan seeking social support dalam merawat pasien, sering meminta bantuan pada pelayanan kesehatan. Ini sesuai dengan fungsi keperawatan keluarga menurut Friedman (2010) yaitu keluarga mampu mempertahankan hubungan dengan menggunakan fasilitas kesehatan masyarakat. Hasil penelitian Chadda, Singh, dan Ganguly (2007) menyatakan bahwa planful problem solving dan seeking social support merupakan strategi koping yang paling sering dilakukan oleh caregiver pasien skizofrenia.

Selain planful problem solving dan seeking social support, dari data pada tabel 2 menunjukkan bahwa sangat sedikit responden yaitu 1 orang $(8 \%)$ yang cenderung melakukan confrontive coping dalam mengatasi masalahnya. Keluarga melakukan confrontive coping untuk mengubah keadaan dengan cara mengekspresikan reaksi agresif, tingkat kemarahan yang cukup tinggi dan pengambilan risiko. Kelelahan yang timbul karena tanggung jawab dalam merawat pasien gangguan jiwa, perilaku pasien yang tidak dimengerti dan tidak dapat diatur akan menimbukan perasaan marah pada anggota keluarga (Sherman, 2008).

Keluarga yang cenderung menggunakan emotional focused coping merupakan keluarga yang menganggap masalah sulit untuk dikontrol, sehingga dalam mengatasi stres, mereka mengatur respon emosional untuk menyesuaikan diri pada situasi yang penuh dengan tekanan (Lazarus \& Folkman, 1984).

Berdasarkan pada tabel 3 dari 20 responden yanglebihcenderungmenggunakanemotional focused coping menunjukkan bahwa setengah responden yaitu 11 orang (55\%) lebih menggunakan positive reappraisal dalam menghadapi masalah. Hasil penelitian ini menandakan keluarga lebih mencari makna positif atau berpikir positif dari permasalahan yang berfokus pada pengembangan diri dan biasanya melibatkan hal-hal yang bersifat religius. Keluarga lebih berusaha menerima dengan ikhlas masalah yang muncul. Penelitian ini sejalan dengan penelitian Hassan et al. (2011) menyatakan bahwa positive reappraisal merupakan salah satu strategi koping yang paling sering dilakukan oleh keluarga dalam merawat penderita gangguan jiwa berat (skizofrenia). Terlihat pula, sangat sedikit responden yaitu 3 orang $(15 \%)$ yang menggunakan strategi koping distancing dalam menghadapi permasalahan. Ini menandakan keluarga terkadang berusaha untuk tidak terlibat dalam merawat anggota keluarga yang mengalami gangguan jiwa berat. Menurut penelitian Hassan et al. (2011) 
Yelsi Wanti: Gambaran Strategi Koping Keluarga dalam Merawat Anggota Keluarga

distancing dapat menurunkan stres bagi keluarga. Ini terjadi karena untuk sementara waktu, keluarga tidak disibukkan dengan hal-hal yang berkaitan dengan penderita gangguan jiwa berat (skizofrenia). Namun, apabila penghindaran terus dilakukan, maka masalah yang ada tidak akan pernah hilang atau terselesaikan.

Sangat sedikit responden yaitu 2 orang $(10 \%)$ yang menggunakan strategi koping accepting responsibility. Ini menandakan keluarga dalam merawat pasien gangguanjiwa berat berusaha untuk menyadari tanggung jawab diri sendiri dalam permasalahan yang dihadapi dan mencoba menerimanya sambil berusaha untuk memperbaikinya. Keluarga yang menggunakan strategi koping accepting responsibility menyadari bahwa sebagai keluarga, mereka adalah orang terdekat pasien dan yang paling merasakan dampak dari penyakit pasien sehingga peran keluarga menjadi caregiver sangatlah penting.

Selain itu, sangat sedikit responden yaitu 1 orang $(5 \%)$ yang cenderung melakukan self control. Self control dilakukan keluarga untuk mengatur perasaan maupun tindakan dalam menghadapi masalah. Anggota keluarga menggunaan self control pada masalah-masalah yang akan menyebabkan pertengkaran antara keluarga dengan pasien (Novita, 2010).Terlihat pula sangat sedikit keluarga yaitu 1 orang $(5 \%)$ cenderung melakukan escapel avoidance. Strategi ini dilakukan keluarga untuk menghindar atau melarikan diri dari permasalahan yang sedang dihadapi. Keluarga lebih memilih untuk melakukan kegiatan lain yang dianggap lebih menyenangkan. Hal ini dilakukan keluarga demi menenangkan emosinya daripada harus memikirkan masalah yang diakibatkan oleh penderita gaangguan jiwa berat di rumah. Escape/avoidance dalam merawat pasien gangguan jiwa berat tidak akan menyelesaikan masalah.

Keluarga yang cenderung menggunakan problem focused coping dan emotional focused coping secara bersamaan merupakan keluarga yang mampu menyelesaikan/ mengubah masalah didampingi oleh pengontrolan emosi. Berdasarkan tabel 4 dari 10 responden yang cenderung menggunakan problem focused coping dan emotional focused coping secara bersamaan diketahui bahwa 3 orang responden $(30 \%)$ lebih cenderung menggunakan seeking social support dan positive reappraisal secara bersamaan. Hal ini dapat diartikan bahwa keluarga dalam menghadapi masalah mencari bantuan dari kerabat, tetangga ataupun orang yang lebih profesional, keluarga akan lebih banyak mendapat informasi untuk menyelesaikan masalah yang ada (seeking social support) sekaligus keluarga mencoba berpikir positif mengenai keadaannya akan memudahkan keluarga untuk berpikir secara matang dan tenang dalam memahami masalah (positive reappraisal). Responden lainnya yaitu 3 orang $(30 \%)$ menggunakan seeking social support dan accepting responsibility secara bersamaan dalam mengatasi tekanan akibat merawat penderita gangguan jiwa berat. Hal ini dapat diartikan bahwa keluarga dalam menghadapi masalah mencari bantuan atau informasi dari kerabat, tetangga atau orang yang lebih profesional (seeking social support) sekaligus keluarga menyadari tanggung jawabnya dalam permasalahan yang dihadapinya dan mencoba menerimanya untuk membuat semua lebih baik (accepting responsibility).

Berdasarkan hal tersebut, keluarga yang cenderung menggunakan kedua strategi koping yaitu problem focused coping dan emosional focused coping secara bersamaan, dapat dikatakan telah memiliki kemampuan untuk memecahkan masalah yang didampingi dengan pengontrolan emosi sehingga tingkat stres yang ada akan mulai berkurang. Hal ini sesuai dengan teori Lazarus dan Folkman (1984) yang mengemukakan bahwa untuk mencapai strategi koping yang efektif diperlukan penggunaan kedua strategi koping.

\section{Simpulan}

Dari seluruh responden/ anggota keluarga yang merawat pasien gangguan jiwa berat, sebagian dari responden lebih cenderung menggunakan emotional focused coping. Ini menandakan keluarga dalam merawat pasien gangguan jiwa berat di rumah melakukan usaha untuk menghadapi stres dengan cara mengatur respon emosionalnya untuk menyesuaikan diri dari dampak yang 
Yelsi Wanti: Gambaran Strategi Koping Keluarga dalam Merawat Anggota Keluarga

ditimbulkan oleh pasien. Sebagian kecil responden cenderung menggunakan problem focused coping dan sebagian kecil responden lainnya dominan menggunakan problem focused coping dan emotional focused coping secara bersamaan.

Jumlah responden yang cenderung menggunakan emosional focused coping, setengah dari responden menggunakan Possitive Reappraisal dalam menghadapi beban merawat anggota keluarga yang gangguan jiwa. Kemudian dari responden yang cenderung menggunakan problem focused coping, setengah dari responden menggunakan planful problem solving untuk menghadapi beban merawat. Dari responden yang dominan menggunakan strategi koping keduanya yaitu PFC dan EFC lebih cenderung menggunakan seeking social support-positive reappraisal dan seeking social supportaccepting responsibility secara bersamaan dalam menghadapi beban merawat pasien gangguan jiwa berat.

Hasil penelitian ini diharapkan dapat memberikan masukan bagi perawat di Puskesmas setempat untuk lebih meningkatkan pelayanan kesehatan terutama pemberian konsultasi dan konseling tentang psikoedukator bagi keluarga yang merawat anggota keluarga yang mengalami gangguan jiwa berat. Pemberian konseling pada keluarga dapat meningkatkan keterampilan untuk dapat memahami koping akibat gangguan jiwa yang mengakibatkan masalah pada hubungan keluarga. Adanya Nursing Center yang lebih berfokus pada perawatan pasien gangguan jiwa berat juga sangat diharapkan karena banyaknya jumlah gangguan jiwa yang ada di kecamatan kersamanah tersebut.

\section{Daftar Pustaka}

Baker, J. P., \& Berenbaum, H. (2008). The efficacy of problemfocused coping and emotional approach coping varies as a function of emotional processing. Cognitive Therapy and Research, 32, 66-82

Chadda, R.K., Singh, T.B., Ganguly, K.K.(2007). Caregiver burden and coping: A prospective study of relationship between burden and coping in caregivers of patients with schizophrenia and bipolar affective disorder. Social Psychiatry and Psychiatric Epidemiology 42: 923-930.

Friedman, M. (2010). Buku ajar keperawatan keluarga : Riset, Teori dan. Praktek. Jakarta : EGC.

Hassan, W.A.N., Mohamed, I.I., Elnaser, A.E.A., Sayed, N.E. (2011). Burden and coping strategies in caregivers of schizophrenic patients. Journal of American Science 7(5): 802-811.

Kementerian Kesehatan RI. (2013). Riset kesehatan dasar. Jakarta: Badan Penelitian dan Pengembangan Kesehatan Kementerian Kesehatan RI.

Lazarus, R. S., Folkman. (1984). Stres Appraisal and Coping. Springer New York : Publishing Company

Magaña, S.,M., Ramírez García, J.,I., Hernández, M.,G., \& Cortez, R. (2007). Psychological distres among latino family caregivers of adults with schizophrenia: The roles of burden and stigma. Psychiatric Services, 58(3), 378-84. Retrieved from http://search.proquest.com/docview/213125 332 ? accountid $=48290$

McMahon, G. (1998). Stres counselling: Rational emotive behaviour approach. British Journal of Guidance \& Counselling, 26(1), 131. Retrieved from http://search.proquest. com $/$ docview $/ 205073364$ ? accountid $=48290$

Mohr, W.K. (2006). Psychiatric Mental Health Nursing. (6 $6^{\text {th }}$ ed). Philedelphia: Lipincott Williams Wilkins.

Nainggolan, N. J. dan Lidia L. H. (2013). Profil Kepribadian dan Psychological WellBeing Caregiver Skizofrenia. $\neg \neg$ Jurnal Soul 6(1).

Nasir, A., Muhith, A. (2011). Dasar-dasar keperawatan jiwa. Jakarta: salemba medika.

Novita, Y. (2010). Coping stres suami yang memiliki istri skizofrenia. http://repository. 
Yelsi Wanti: Gambaran Strategi Koping Keluarga dalam Merawat Anggota Keluarga

usu.ac.id/bitstream/123456789/14542/1/1 0E00127.pdf (diakses tanggal 28 juni 2015).

Rammohan, A., Rao, K., Subbakrishna, D.K. (2002). Burden and coping in caregivers of persons with schizophrenia. Indian Journal of Psychiatry, 44(3):220-227.

Retnowati, R. (2012). Strategi koping keluarga dalam merawat anggota keluarga penderita skizofrenia di Instalasi Rawat Jalan Rumah Sakit Jiwa Provinsi Jawa Barat. http://jurnal.unpad.ac.id/ejournal/ article/view/723 (diakses pada tanggal 10 mei 2015).

Sacks, Susan Bendersky, MSN,R.N., C.S.
(2004). Rational emotive behavior therapy. Journal of Psychosocial Nursing \& Mental Health Services, 42(5), 22-31. Retrieved from http://search.proquest.com/docview/22 5540774? accountid $=48290$

Setiadi, I. (2006). Skizofrenia: Memahami Dinamika Keluarga Pasien. Bandung: Refika Aditama.

Sherman, M. D. (2008). Support and family education. Oklahoma City Veterans Affairs Medical Center Affiliate Research Investigator, South Central MIRECC.

Videbeck, S. L. (2008). Buku ajar keperawatan jiwa. Jakarta: EGC. 